\title{
THROUGH THE APULIAN STREETS: THE LIMINAL SPACE-TIME OF THE HOLY WEEK'S PROCESSIONS
}

\author{
Vito Carrassi \\ Independent scholar \\ Email: vito1976@interfree.it
}

\begin{abstract}
My article, building on fieldwork carried out between 2013 and 2015, focuses on the importance, significance and specificity that the religious and devotional processions have in many Apulian sites. This is particularly clear for the Holy Week, whose rituality is generally characterized by a complex and manifold set of performances primarily taking place within and along the city/ town streets. Referring to the Bakhtinian concept of chronotope, the street may be regarded as a liminal space-time where the inhabitants meet, confront each other and live day by day, giving rise to the everyday and common dimension of their existence. Yet, on given occasions (during the Holy Week, for instance), the streets can be turned into a sort of open stage, temporarily and exclusively dwelt with and managed by certain individuals and groups, first and foremost the laical confraternities. These people, through their performances, act as mediators between the common and the uncommon, the secular and the sacred, the worldly and the otherworldly; in so doing, they stage a ritual drama by which some sacred symbols (in particular the simulacra representing Christian figures and dogmas) leave their ordinary, static dimension (enclosed in the churches) to acquire an extraordinary, dynamic, and more engaging role. Nowadays, this is an essential means through which local communities seek both to preserve/strengthen their identity and to promote their cultural heritage.
\end{abstract}

Keywords: Apulia, chronotope, Holy Week, liminality, procession, religion, ritual year, space, street, time

\section{INTRODUCTION}

This paper takes the cue from the fieldwork I carried out in some Apulian cities and towns (southern Italy) between 2013 and 2015, as part of a research project named "Puglia in festa - Valorizzazione dei beni immateriali della Puglia" (Festive Apulia - Promotion of the Apulian Intangible Heritage), whose goal was to collect, catalogue, and archive the intangible cultural heritage of Apulia, with special regard to the ritual year and its festivals. ${ }^{1}$ In particular, my focus here 
is upon a specific form of ritual performance, the procession, which is arguably the most widespread and multifaceted among the ritual performances characterizing the lively and quite intense religious and devotional life of so many Apulian and, more generally, southern Italian communities (for a broad and in-depth historical and sociological overview see Pizzuti et al. 1998). A procession, after all, is one of the most complex and impressive means of expression, enactment and embodiment of traditional beliefs, myths, symbols, meanings, feelings, and values for the members of a local community. ${ }^{2}$ From this perspective, the procession may be regarded as a set of more or less formalized practices through which certain individuals and groups, by occupying and employing some given places and locations within the city/town, temporarily re-shape and re-define the urban landscape commonly dwelt and lived by themselves and the other inhabitants (cf. Krom 2009: 34-35). Through a set of more or less organized performances, the procession-doers (and, to a lesser extent, their audiences) transform ordinary and everyday spaces into special settings bound to carry out an extraordinary task, in order to make possible the displaying and the sharing of paradigmatic worldviews, symbols, and values. ${ }^{3}$ What follows is intended to be a brief contribution to the knowledge, analysis, and interpretation of such a subject in the specific context of the Apulian region.

\section{THEORETICAL FRAMEWORK}

The abovementioned notion of ordinary and everyday space appears to be particularly fitting to define the main setting of a ritual procession: the street. In a broader sense, this is a key element both in the structure of a city/town, and in the lives of its inhabitants. ${ }^{4}$ Along the streets, day by day (or on certain days), people walk, run, move from one place to another, go to work, meet other people and talk to them, stop before a shop or a billboard, watch and evaluate the urban changes, and so on: in other words, the streets are a sort of public arena where individuals and groups can create and strengthen (but also release or undermine) the bonds connecting a local community or an urban society (see Lenzini 2017). The streets, so to speak, allow the juxtaposition and the interplay between the public and private domains of our lives.

Basically, a street may be seen as an open and (as a rule) free stage where a large and always changing variety of actors play, more or less consciously, a drama - the drama of everyday life of a city/town. As a place entailing a drama, a set of actions happening not only within a certain space, but also during a certain time, the street may also be conceived as a complex space-time entity, where the two fundamental axes shaping our perception of reality act and 
influence each other. In this light, the well-known concept of chronotope seems to be still helpful and profitable (cf. Blommaert 2018). According to Mikhail Bakhtin (2002: 15), the chronotope identifies "the intrinsic connectedness of temporal and spatial relationships that are artistically expressed in literature".

Paraphrasing, we could state that the chronotope describes the intrinsic connectedness of temporal and spatial relationships that are ritually expressed in the dramas performed within and along the streets. In the following lines, the Russian scholar better explains what he means when speaking about the close relationship linking space and time:

What counts for us is the fact that it expresses the inseparability of space and time... . In the literary artistic chronotope, spatial and temporal indicators are fused into one carefully thought-out, concrete whole. Time, as it were, thickens, takes on flesh, becomes artistically visible; likewise, space becomes charged and responsive to the movements of time, plot, and story. This intersection of axes and fusion of indicators characterizes the artistic chronotope. (Bakhtin 2002:15)

In other words, time would be something intangible and purely theoretical without the concrete, tridimensional arena supplied by the space (by a street, for instance); likewise, the space would be lacking of meaning and measure if not integrated within the diachronic, historical framework provided by the time (and all human actions, whether ritual or not, take place in a well-defined time frame). However, what makes a 'chronotopic' understanding of the street extremely significant is the fact that Bakhtin envisions the street (the road, indeed) not as a solely spatial feature of a chronotope, but as a chronotope in itself:

On the road ("the high road"), the spatial and temporal paths of the most varied people ... intersect in one spatial and temporal point.... On the road the spatial and temporal series defining human fates and lives combine with one another in distinctive ways... . The chronotope of the road is both a point of new departures and a place for events to find their denouement. Time, as it were, fuses together with space and flows in it (forming the road) ... varied and multi-leveled are the ways in which road is turned into a metaphor, but its fundamental pivot is the flow of time. (Bakhtin 2002: 17; emphasis mine)

According to Bakhtin, the road - and then the street ${ }^{5}$ - reveals an inherent dramatic nature and vocation, as it supplies a spatial frame especially suitable for the unfolding of time, then of the human events, lives, fates, their combinations and intersections ("[t]ime ... flows in it (forming the road)"). Consequently, 
how not to consider the street as the ideal stage where to display, represent, celebrate - both physically and figuratively - myths, beliefs, and stories concerning the identity of a human community?

Interestingly, the Bakhtinian taxonomy of the literary chronotopes includes also that of threshold, which further stresses the ritual and dramatic features implied in a street. ${ }^{6}$ If conceived as thresholds, the streets, indeed, may be regarded as liminal spaces, or better, as liminal space-times situated between those places (the buildings) which make up the urban landscape and are ordinarily dwelt, employed, and lived by its inhabitants. In other words, the streets provide the space-time through which the static components of the city/town can be connected, and what is contained in them can be made dynamic, put in motion, given life, so to speak. This is particularly important for those things that are considered sacred or highly significant by the community and, just for that reason, lie usually enclosed, fixed, hidden within the boundaries of their consecrated and official abodes. As a result, the inherent liminality of the street takes on a potential relevance as a ritual and performative framework. Victor Turner has pointed out (1988: 25):

The dominant genres of performance in societies at all levels of scale and complexity tend to be liminal phenomena. They are performed in privileged spaces and times, set off from the periods and the areas reserved for work, food and sleep.

According to this view, a ritual event, given its liminal condition, needs to be performed in a neutral space-time - "betwixt and between", to use a renowned phrase (see Turner 1967: 93-111) - somehow separated from the common places of the everyday life (and from the common people), but, at the same time - due to its collective and shared significance - it must be set into the heart of a community, in a place that all its members may access. A ritual performance, in fact, functions as a kind of social metacomment, "a story a group tells to itself and about itself" (Turner 1982: 104). To this end, the ordinary, customary perception of reality is temporarily suspended, ${ }^{7}$ the everyday ways and rhythms of human life are momentarily stopped or slowed down, in order to make room for a different space-time configuration. Turner (1988: 102) has resumed it brilliantly, saying:

[The liminality] is often the scene and time for the emergence of a society's deepest values in the form of sacred dramas and objects - sometimes the reenactment periodically of cosmogonic narratives, or deeds of saintly, godly, or heroic establishers of morality, basic institutions, or ways of approaching transcendent beings or powers. 


\section{HOLY WEEK'S PROCESSIONS IN APULIA}

This last excerpt seems deliberately thought to introduce and summarize the subject I am going to discuss. To be sure, the concept of liminality, combined with the chronotope of the road/street, has turned to be especially suitable for addressing and understanding the ritual procession, namely the form of traditional performance most frequently observed throughout the fieldwork I carried out across the Apulian region. Here as elsewhere, processions are typical of a number of festivals marking the ritual year, such as the patron saint's celebrations or the carnival's parades, yet the centrality and the variety they have in the broader context of the Holy Week's religious and civil calendar are incomparable, at least in the light of my personal experience, both as a scholar and as an Apulian native and inhabitant. Consequently, my analysis, building both on the data collected on the field and on archival materials (most of them published in Nigro 2002, and Altomare 2011), focuses on this particular subject.

To my knowledge, the use and practice of providing a dramatic form - and specifically a processional form - to the sacred events commemorated during the Holy Week is present, to a variable extent, everywhere in Apulia (see Di Palo 1992). ${ }^{8}$ In fact, the Holy Week is generally felt and lived, both from a religious and popular perspective, as a crucial, emblematic period of the year, as a sort of temporal and paradigmatic threshold (Van Gennep 2004 [1960]: $3-4)$, marking both the natural succession of the seasons - from the bad to the good season (Bronzini 1974: II, 33-34, 61) - and the calendrical transition from Lent to Easter, then from a period of restraint and penance to a day of abundance and rejoice.

As a liminal time (Bernardi 1991: 49-52), the Holy Week needs a liminal space to express itself; this space, however, must be also wide and open enough to house the related ritual performances, while allowing a large audience to attend them. That is why the streets, during this period, become the main stages of a religious and devotional drama, then the center itself of the city/town; a mobile and not static center, around which the local community - along with an increasing number of foreigners and tourists - gathers. For the time being, some streets - namely the streets included in the processional itinerary, which tends to remain the same over the years, except for changes owing to the urban evolution or contingent reasons ${ }^{9}$ - dismiss their mundane nature and common purpose to assume a symbolic function and transcendent value.

Actually, the streets are not the only setting of the Holy Week's ceremonies. Several of them are necessarily celebrated within the holy buildings (churches, chapels, sanctuaries), that is, where the religious items and the sacred images are housed and where the clergy, together with the common faithful, celebrate 
the liturgical and devotional practices. Nonetheless, it is in the streets that the most dramatic rituals - the processions - take place; during these rituals, simulacra and other sacred symbols, embodying community's shared beliefs and values, are exceptionally taken out from their shrines and put in motion across the city/town. This double setting gives rise to an essential and functional dialectic between the enclosed and the open, the inside and the outside of the Christian (para)liturgy and rituality (churches vs. streets), then between their static (or relatively static) and dynamic (or relatively dynamic) dimensions (Masses and other liturgies vs. processions).

In most Apulian cities and towns, therefore, the main ceremonies of the Holy Week, in particular those celebrated on Maundy Thursday and Good Friday, are based on and characterized by this dialectic. The processions, in a sense, may be seen as traditional and more popular extensions - into the open and common space of the city/town - of the respective liturgical rituals - embodying, in their turn, the official and dogmatic side of the religious beliefs and practices; better, the processions always originate and finish within the sacred space of a church but, in the meantime, make available, theoretically for everyone, what is usually available only if one enters the closed space of a holy building.

During Maundy Thursday (cf. Bernardi 1991: 65-87), a solemn liturgical commemoration of the Last Supper (including a feet washing performed by the priest on twelve men or, more frequently, boys/girls representing the apostles) is celebrated in the evening (approximately between 6 and $8 \mathrm{pm}$ ) within the churches. It is followed, in many cities and towns (first and foremost Taranto), by some informal or barely formalized processions (usually the vehicular traffic is not or is only partially interdicted) of pairs or small groups of hooded 'brothers', popularly known as Perdoni - i.e., those who beg forgiveness - or the like. Crossing by foot the city/town from late evening to the night (or, like in Taranto, to the early morning), they visit the churches in order to pray and do penance (usually standing on their knees) before the Holy Sacrament, which, in this day, is also visited by a great deal of common people and is emphasized by a striking symbolic decoration (popularly and incorrectly known as Sepolcro, i.e. 'grave') displaying the dogma of the Eucharist (see Fig. 1).

As for Good Friday (cf. Bernardi 1991: 89-121), following an afternoon's restrained liturgy (named messa pazza, literally "mad Mass", in Vico del Gargano) recalling the Passion and Death of Jesus Christ (including the dramatic reading of Passio Christi and pious sermons intended to inspire regret and contrition), a solemn and crowded procession, usually known as the procession of the Misteri (Mysteries), starts from the cathedral, the mother-church or a confraternal church, moves along the main roads of the older and central part of the city/town, between a great deal of people attending on the borders 
(or from above, through windows or on balconies), and finally, after some hours (from a minimum of about 3 hours, like in Vico del Gargano, to a maximum of 16-17 hours, like in Taranto), comes back to its starting point, drawing a sort of circular itinerary. This procession generally consists of papier-mâché and/ or wooden simulacra representing the figures and the moments of the Passion and Death of Jesus Christ, known as the Misteri, whose number varies from two in Vico del Gargano to over 40 in Valenzano (near Bari), with an average of 5-10 simulacra (see Fig. $2 \& 3$ ); ${ }^{10}$ their carriers and escorts, first of all the confraternities (see Fig. 4 \& 5), often joined by other people (sometimes in the form of incappucciati, that is, individuals covering their face by a hood) expressly recruited for the procession (see Fig. 6); men and women usually dressed in black to express their mourning - to this end, the women escorting Our Lady of Sorrows sing mournful songs (see Fig. 7); ecclesiastical, civil and military authorities; musical bands playing funeral marches; and, at the end of the parade, a gradually growing crowd of the common faithful who leave their place on the borders of the street as audience and join the procession. ${ }^{11}$

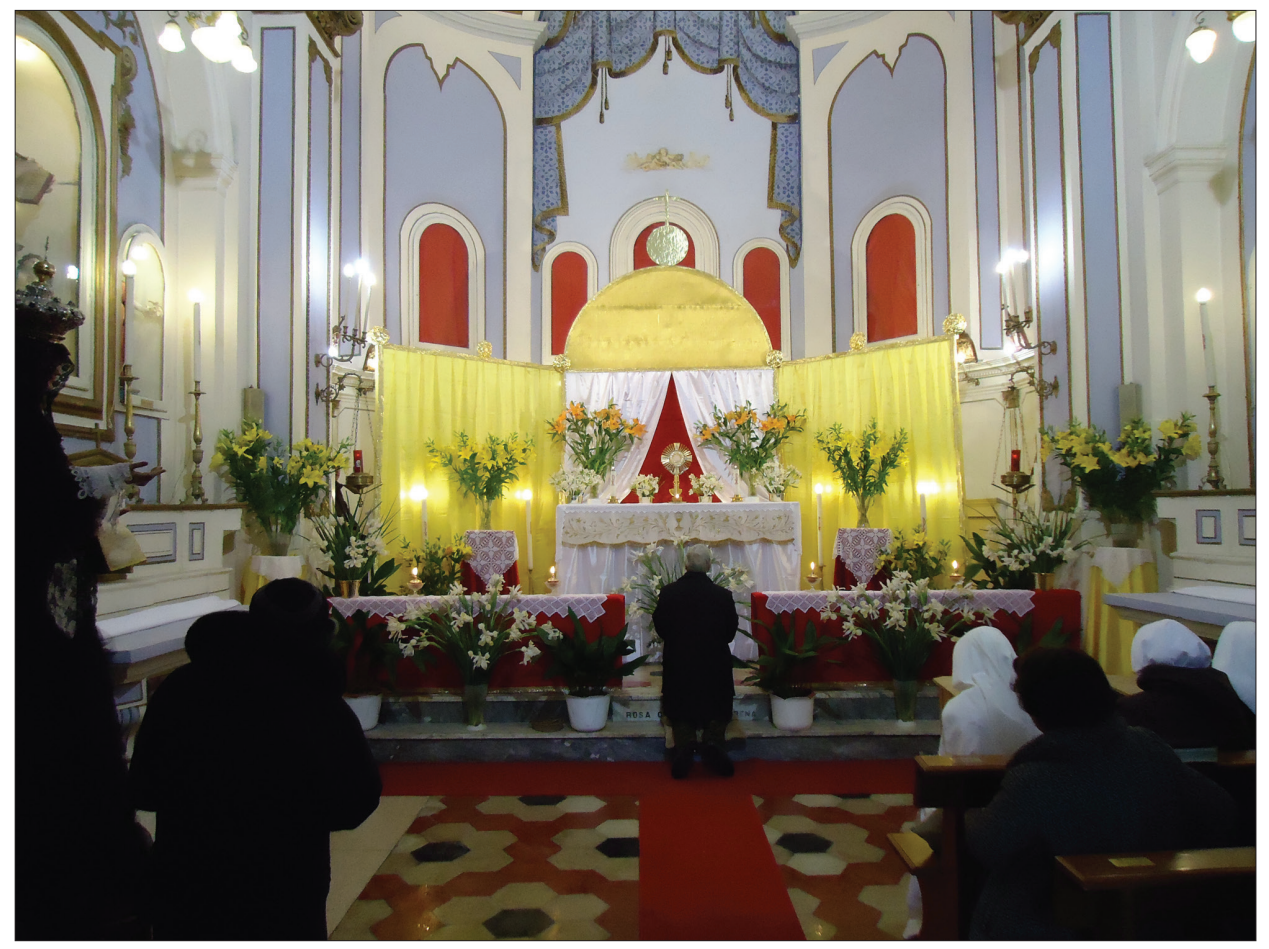

Figure 1. Sepolcro set up for Maundy Thursday in the church of Misericordia (Mercy), Vico del Gargano. Photograph by Vito Carrassi 2014. 


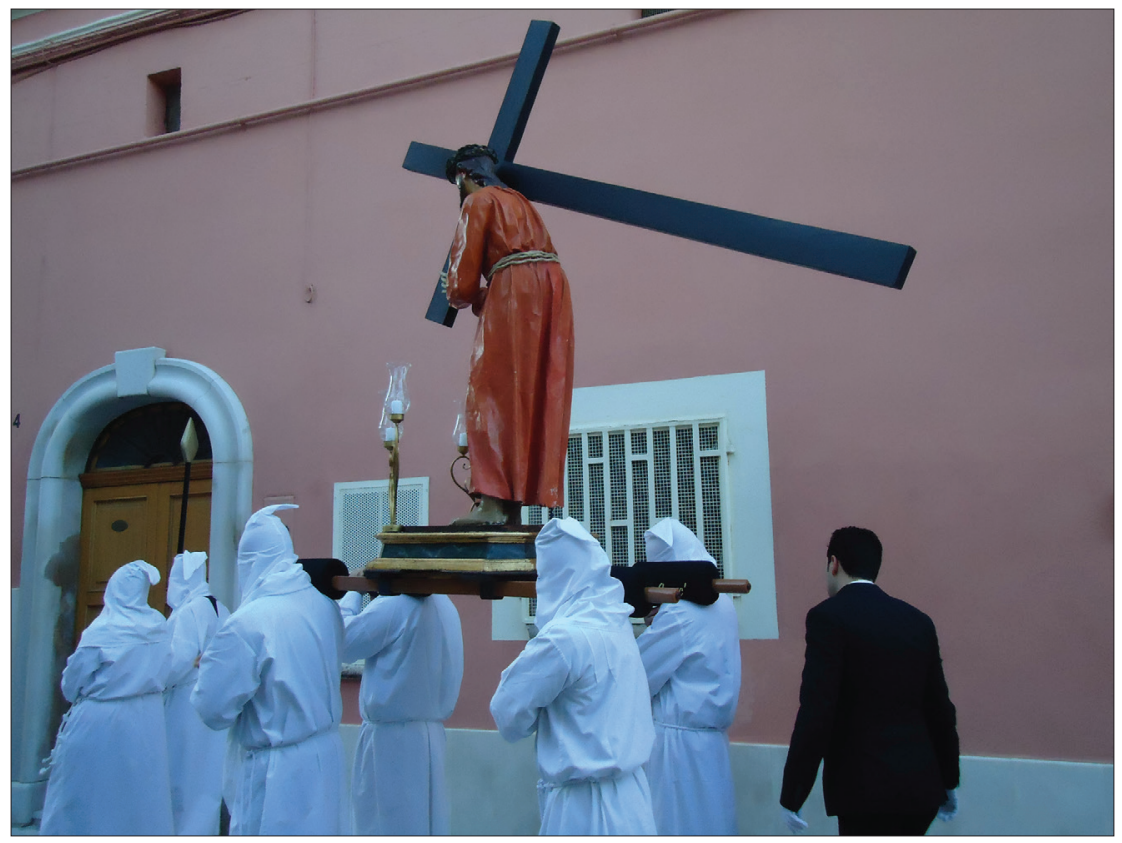

Figure 2. Christ carrying the cross, one of the simulacra carried in procession in Castellaneta on Good Friday. Photograph by Vito Carrassi 2015.

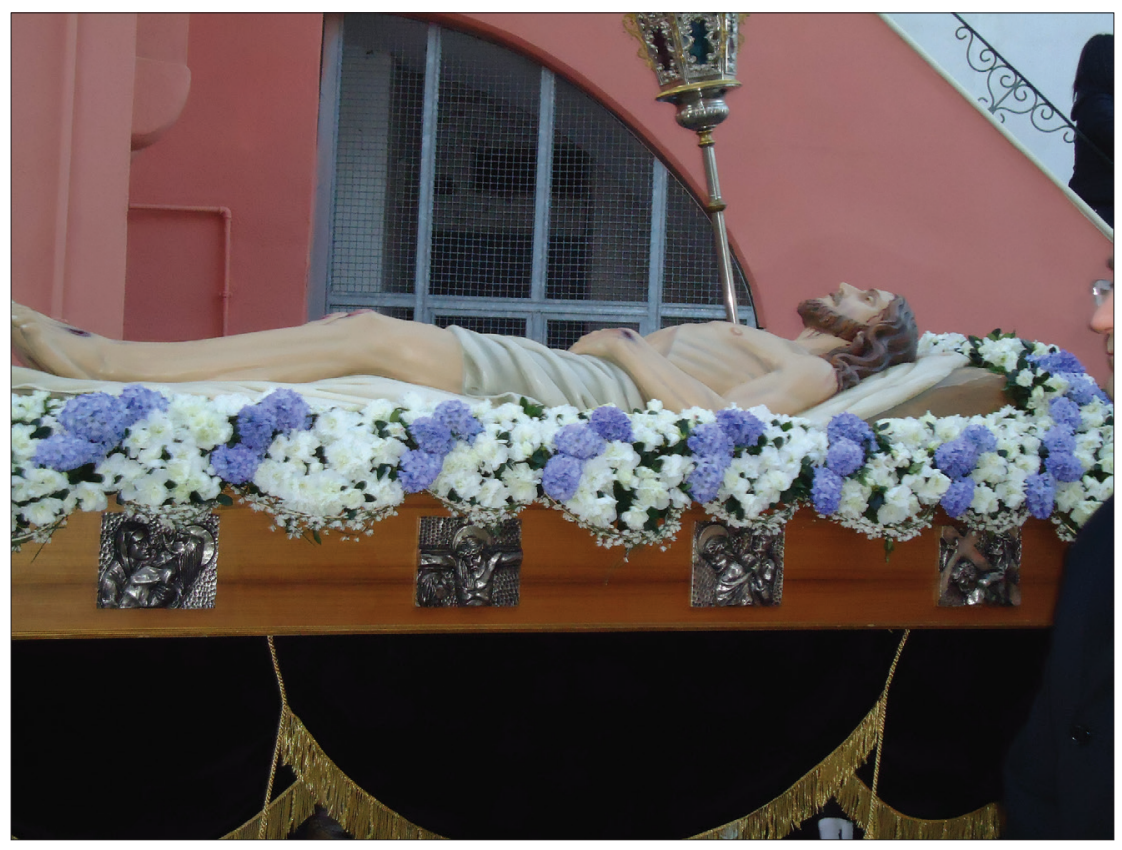

Figure 3. The dead Christ, carried in procession in Castellaneta on Good Friday. Photograph by Vito Carrassi 2015. 


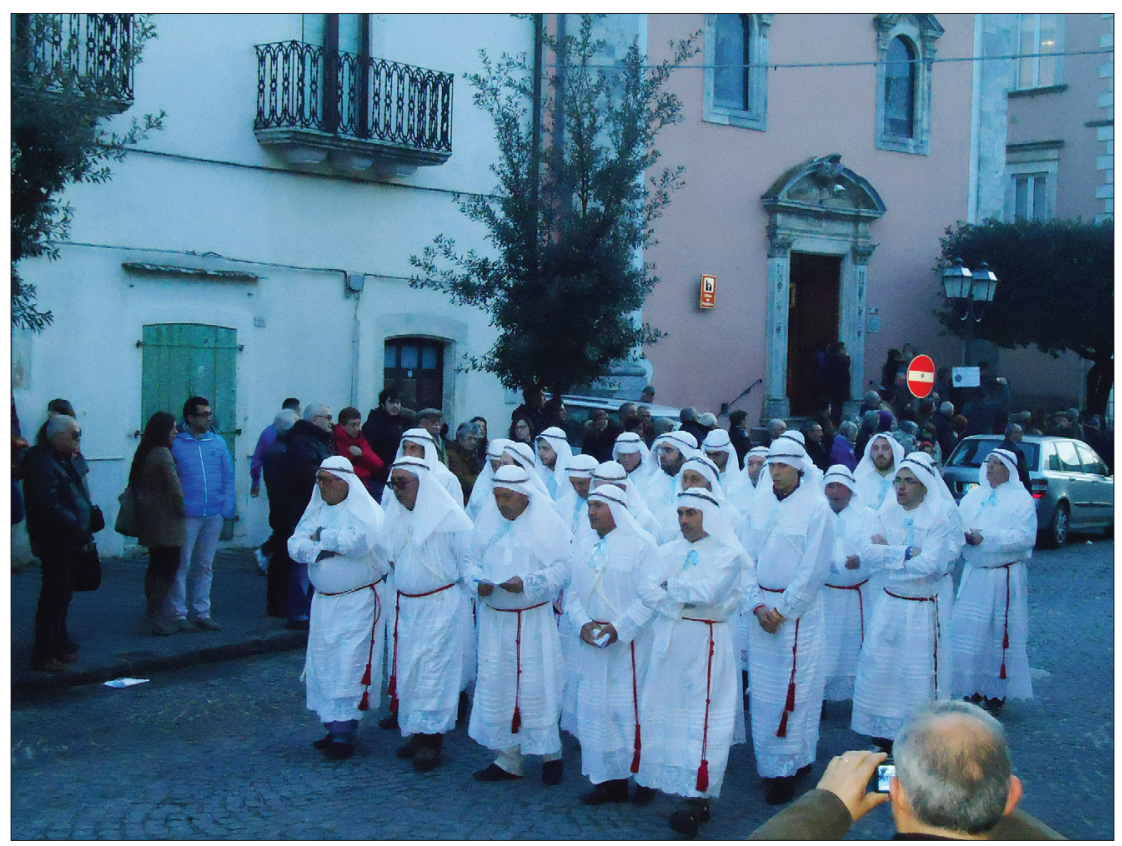

Figure 4. Confraternity of San Pietro (Saint Peter) in procession in Vico del Gargano on Good Friday. Photograph by Vito Carrassi 2014.

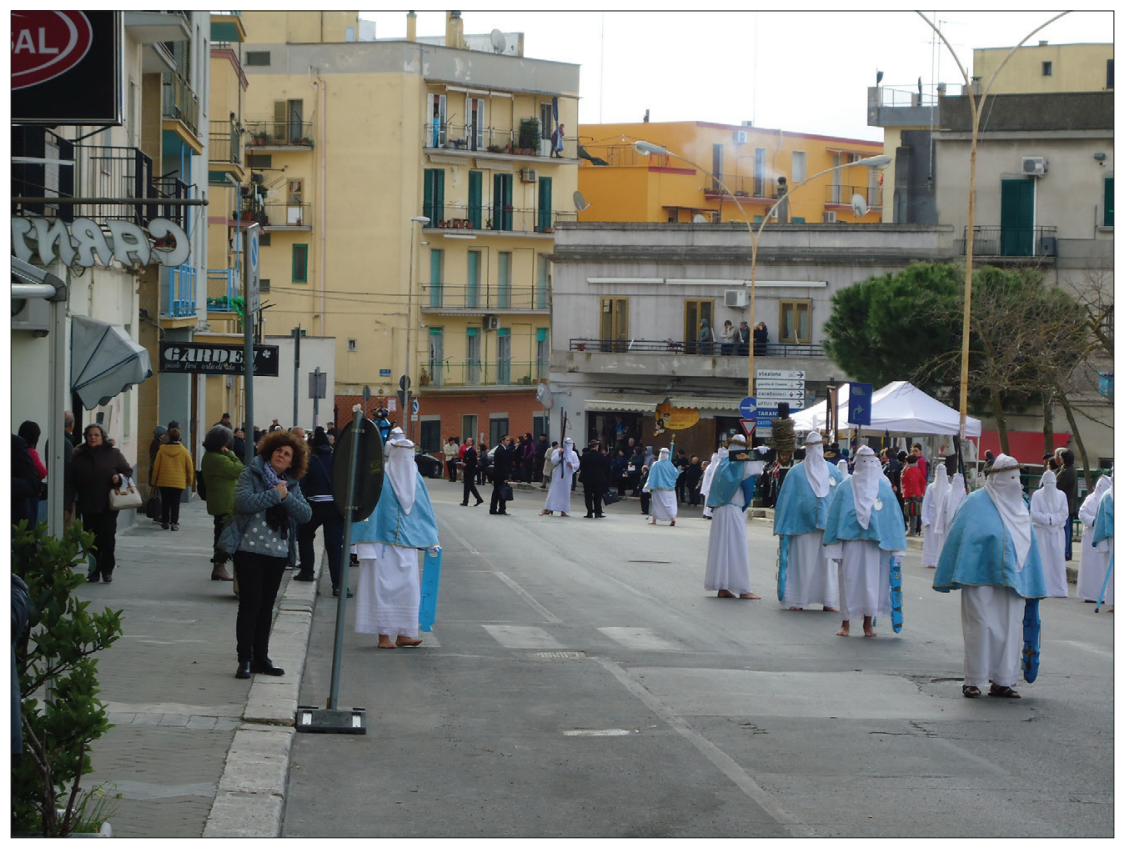

Figure 5. A group of Brothers of the Santissimo Sacramento (Holy Sacrament) in procession in Castellaneta on Holy Saturday. Photograph by Vito Carrassi 2015. 


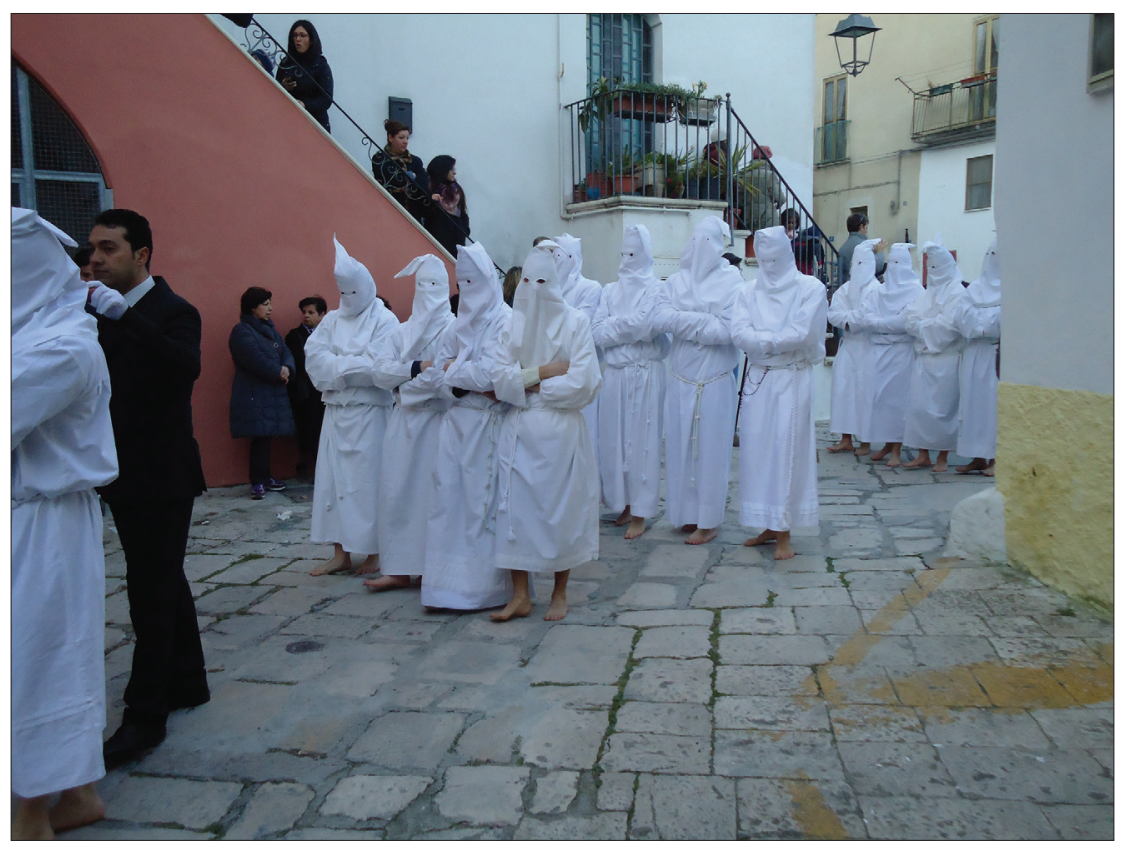

Figure 6. A group of incappucciati (hooded men) in the Good Friday procession in Castellaneta. Photograph by Vito Carrassi 2015.

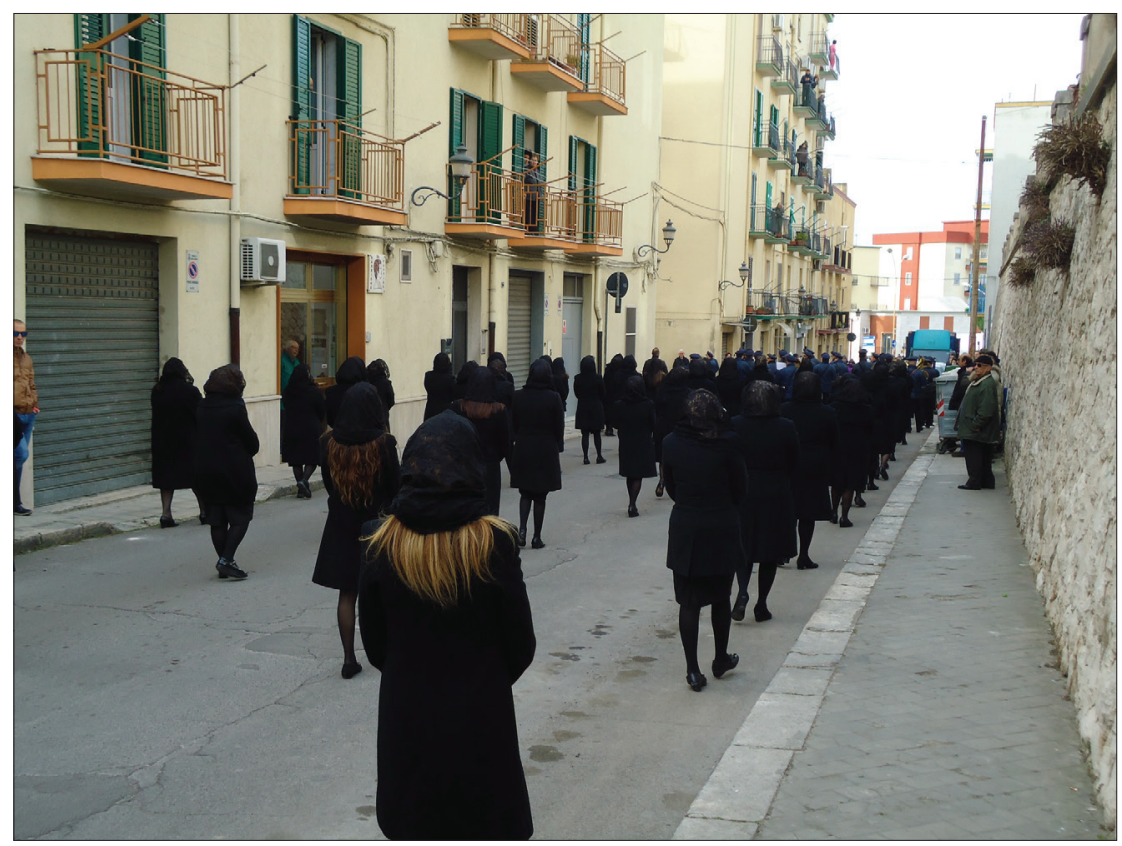

Figure 7. Women dressed in mourning in the Holy Saturday procession in Castellaneta. Photograph by Vito Carrassi 2015. 
In order to exemplify the variety observed on the field, and the local interpretations of the general structure sketched above, I propose three paradigmatic cases which may be considered as three different ways of conceiving and structuring the Holy Week's public rituality, in particular as regards the number, the distribution, the duration, and the mutual proximity of the processions:

1) Castellaneta (near Taranto) shows the most conventional and systematic structure, perfectly corresponding to the liturgical calendar. There are three processions, one for each day of the holy triduum, each well separated from the other. Penitential processions are informally and independently performed by individual confraternities, who visit the town's churches from the evening to the night of Maundy Thursday. A solemn procession of Mysteries, starting from and ending in the cathedral, is performed from the afternoon to the night of Good Friday (lasting about 7-8 hours). A solemn procession devoted to Dead Christ (and Our Lady of Sorrows), starting from and ending in the cathedral, is performed from the early morning to about noon of Holy Saturday (lasting about 6-7 hours).

2) Taranto, whose Holy Week's rituality is the most renowned outside the Apulian boundaries (see Caputo 1995 [1989], 2010 [1983]), is likewise characterized by three main processions, but they are distributed on two days, Thursday and Friday (even if the last procession stretches to the early morning of Saturday), and have a much longer duration; moreover, there is temporal proximity between the end of a procession and the start of the succeeding one. Single pairs of Brothers of the Mount Carmel, from the early afternoon to the night between Thursday and Friday, perform a penitential procession by visiting the city's churches. The confraternity of Our Lady of Sorrows, from the midnight of Thursday to the early afternoon of Friday, perform a solemn procession devoted to the Sorrows of Virgin Mary (lasting about 14-15 hours). Finally, from the early Friday afternoon to the early hours of Saturday, a solemn procession of Mysteries is performed by the confraternity of the Mount Carmel (lasting about 16-17 hours). Interestingly, there is a chronological inversion between the celebration of Passion (and Death) and that of the Sorrows of Virgin Mary. The latter, on the other hand, is more popular and touching for the locals than the former; according to my informant Enzo, "the procession devoted to the Sorrows of Virgin Mary, although less magnificent than that of Mysteries, is emotionally much more involving: you can feel a real sense of sorrow" (personal communication 2014). 
3) Vico del Gargano, a little town located in Gargano community (northeastern Apulia), concentrates its processional rituality, instead on only one day, Good Friday, which is lived as the very heart of the year. As said by my informant Leonardo: "For Vico the Holy Week is the climax of the year ... if I speak as a brother, well, I can tell you that Good Friday is all for me" (Carrassi 2016: 111). Here the role of the confraternities is even more prominent than elsewhere, above all because of their singing, which impressively characterizes the two processions (not three) taking place during the day. From the early morning to about noon, the five confraternities, each with their own simulacra of the Dead Christ and Our Lady of Sorrows, ${ }^{12}$ move from one church to another and, along the path, they never stop singing penitential songs. From about 7 to $10 \mathrm{pm}$, the same confraternities stage a procession of Mysteries - consisting of only two simulacra (the Dead Christ and Our Lady of Sorrows) - which goes from the mother-church to a symbolic place representing the Calvary; along the path each confraternity, one at a certain distance from another, never stops singing the Miserere (taken from Psalm 51), producing a suggestive polyvocal concert. Coming back from the Calvary to the mother-church, both the confraternities and the common faithful following the procession never stop singing, deliberately out of tune, a joyful and messy traditional song, Evviva la Croce (Hurrah the Cross), in order to celebrate in advance Easter and the Resurrection.

On the one hand, the open and dynamic enactment of these religious practices was originally devised to enhance, emphasize, make more concrete and appealing the articles of faith daily or weekly invoked and recalled during the Masses or any kind of prayers. In fact, there are still many people, both among the performers and the audience, who live the processions as highly compelling experiences, often identifying themselves with the characters and the events represented: I think especially of those women who deeply feel the maternal grief expressed by Our Lady of Sorrows, or those men who undergo the exhausting task of carrying a heavy cross in order to emulate the pain suffered by Jesus Christ. Yet, on the other hand, these performances must be understood as a wider and more complex phenomenon. Here, the official and orthodox forms of faith and devotion meet their traditional, unofficial, more or less secularized counterpart, sometimes giving rise to expressions of magic and superstition (see Rivera 1988, in particular 19-29); the religious, clerical motivations coexist and deal with several diverse and changing motivations arising from the lay or less religiously connoted shares of the community (cf. Bernardi 1991: 383-388). Though being ritual ceremonies conceptually meant to convey 
a Christian message and inspire pious thinking, in more practical terms these sacred performances are also theatrical - as they were, in a more pronounced and deliberate way, for so many centuries (Bakhtin 1984: 196-277; Toschi 1955) - and as such need to be considered as well. Through their materiality, indeed, the processions are primarily designed to re-enact and try to make tangible a mythical space-time and a sacred subject; in a sense, they convert "ideas, products of the mind (mentifacts), into material objects 'out there" (Leach 1976: 37). Nevertheless, as a public and well-structured event, their success depends on the role played by a number of members of the community, as well as on their competence, diligence, and motivation.

It is worth stressing, in this light, the ever growing importance the Holy Week's ritual performances have gained in the past years, not only as a means to preserve, retrieve, rebuild or (re)invent a local and traditional identity, but also - as a consequence, I would say - as a tourist attraction (see, e.g., Ringer 1998; McKercher \& du Cros 2012 [2002]). This is proved by a general trend marked by practices of objectification, commercialization, and mediatization, designed to highlight and promote what is increasingly seen as an intangible heritage worth safeguarding (Kirshenblatt-Gimblett 1998; Bravo \& Tucci 2006; Hafstein 2018). More particularly, I have directly observed on the field a largescale printing and circulation of billboards, leaflets, and booklets publicizing and even memorializing the processions, ${ }^{13}$ the setting up of exhibitions displaying ritual objects and related historical documents (see Fig. 8), the organization of photographic contests aimed at selecting pictures to be used as promotional means, the retailing of gadgets and souvenirs representing actors and items of the Holy Week (see Fig. 9), and the live shooting of the processions by local or regional televisions and websites. ${ }^{14}$ But I think that the most impressive and pervasive thing I have experienced is the myriad of smartphones and assorted devices by which a growing number of spectators - but also of performers photograph and/or film the processions. Apparently, everyone wants to capture his/her own snapshots and store them in the virtual memory of his/her device. In this way, actors and moments of the procession are decontextualized and made freely available after the ritual event, so that they can be seen again, shared with (virtual) friends or even used as profile pictures or desktop wallpapers.

As a result, while the attendance and the involvement in such processions necessarily entail a certain degree of individual, family or collective faith and devotion (more or less religiously connoted), their organization and realization requires a relevant effort of coordination and collaboration by a number of committees, associations, and institutions, as well as the proper arrangement of cultural, social, political, and economic resources and purposes. Ignazio Buttitta (2002: 215) has argued: 
Procession has fundamentally the effect of gathering a whole community by suspending, though for a limited space-time, the real or ideal split of the town and its inhabitants. The procession is a moment of cohesiveness and solidarity where ... everybody is called to do their part, to be an actor of the rite.

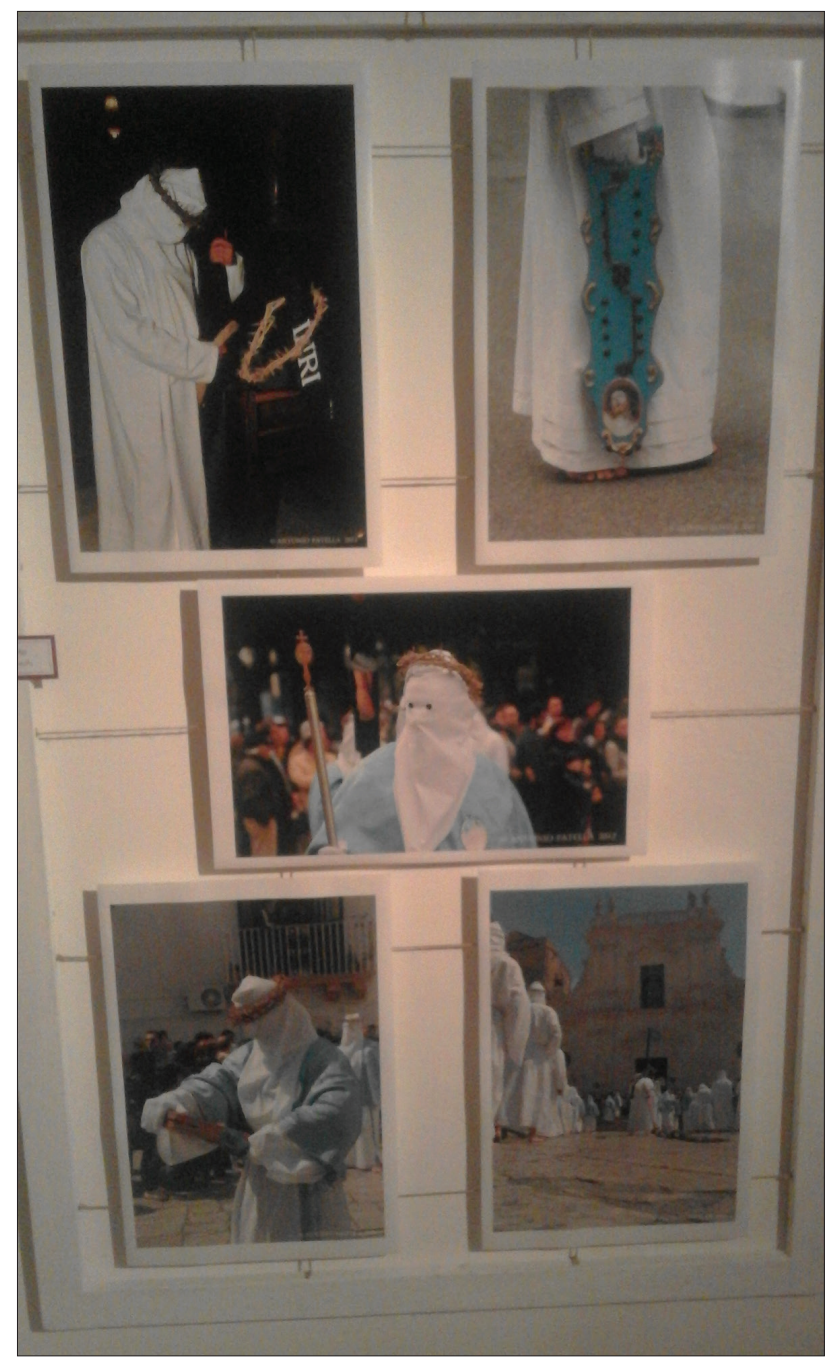

Figure 8. Pictures devoted to the Holy Week, displayed in a public exhibition in Castellaneta. Photograph by Vito Carrassi 2017. 


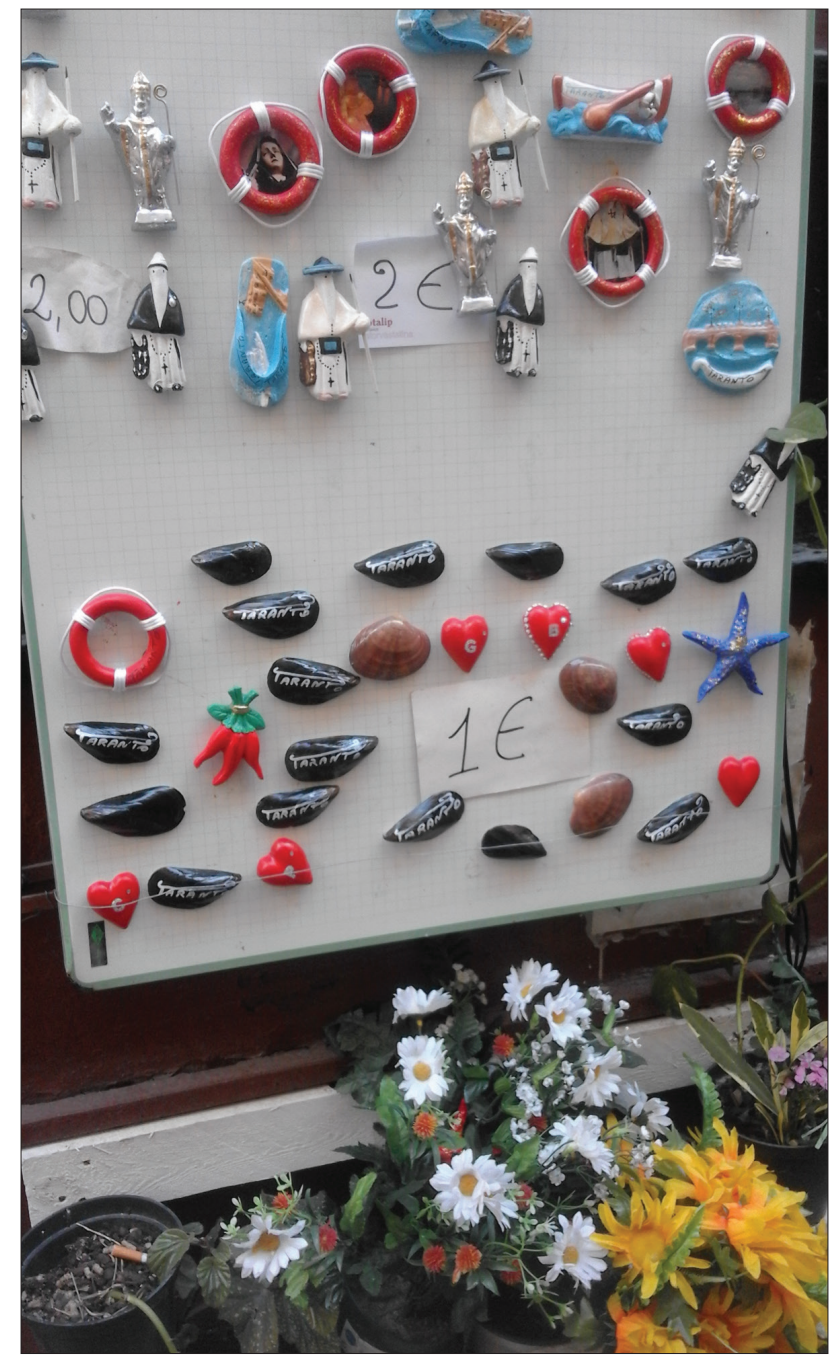

Figure 9. Gadgets representing figures of the Holy Week (those costing 2 euros) displayed in a little shop in Taranto. Photograph by Vito Carrassi 2017.

"Everybody is called to do their part, to be an actor of the rite," but it is quite clear that the most important and significant part is usually played by a particular kind of formal associations, widespread and deeply rooted everywhere in the south of Italy - the laical confraternities. ${ }^{15}$ These men and women, united by a common religious sentiment establishing a mutual solidarity (regardless of their different cultural, social or economic standing), ${ }^{16}$ are gathered around 
a specific devotion to a Christian dogma (such as the Holy Sacrament, the Crucifix or the Purgatory), to the Virgin Mary (especially as Our Lady of Sorrows and as Lady of the Mount Carmel) or to a saint. ${ }^{17}$

During the Holy Week (as well as other festivities of the ritual year) they temporarily leave their everyday, mundane role to take on a special, symbolic status; this is materially suggested by their unusual, clerical-like clothing, generally made up of a long white (or, less frequently, colored) ${ }^{18}$ alb, a colored mozzetta (a sort of short cloak, whose color identifies a single confraternity), and a white or colored hood, which may or may not cover the face; in addition, as a sign of penitence, they often go barefoot, sometimes carrying on their head a kind of crown of thorns. ${ }^{19}$ Thus they acquire a liminal condition, which allows them to appropriately dwell and manage the liminal space-time characterizing the Holy Week's ritual performances; in other words, the confraternities, in the name and on behalf of their fellow citizens, act as mediators between the natural and the supernatural, the human and the divine, the visible and the invisible (Carrassi 2016: 114; Toschi 1955: 79-103).

Once the streets are gradually covered by the processional route, one might say that the brothers take possession of them; for some hours, those streets, usually belonging to nobody (because they are commonly at the service of everybody), become a sacred stage separated from the ordinary, a sort of free zone reserved to the brothers and the other ritual performers. Accordingly, just for the duration of the procession (basically, once the procession has passed, everything gets back to normal), those same streets become forbidden to people and things, uses and purposes unrelated to the ritual performance. While in the rest of the city/town, that is, outside of the processional area, nothing changes - at least not directly, since the interdiction of some streets inevitably affects the daily routine, especially the traffic of the neighboring streets - along the streets destined to the procession new rules are temporarily applied. In particular, parked vehicles must be removed well in advance, in order not to hinder the passing of the procession (of course, the vehicular traffic, for the time being, is stopped), and the common people (i.e. those who are not involved in the ritual performance) should stay on the borders without crossing the street before the procession has passed; they may only attend as an audience, therefore they must remain at a distance (sometimes secured by metal barriers) both from the human and the inanimate (the simulacra) actors of the procession, so as not to interfere with their performance and, at a higher level, not to perturb the sacred liminality of the ritual space.

By following their path across the urban landscape, the confraternities "sketch a precise sacral geography" (Buttitta 2002: 210) and stage, along with the other actors, the advent of a different conception and perception of time. 
This is a time primarily marked by the commemoration of Christian Mysteries and aimed (at least in theory) at inspiring repentance and moral conversion into the faithful / the audience, who for the most part attend in silence or comment quietly what they see, traditionally making the sign of the cross before each simulacrum; the predominant and distinctive sound of these moments is usually the deafening and monotonous sound generated by the so-called troccola (ratchet, noisemaker) and other traditional percussion instruments, played by the brothers but also by common people (Bronzini 1974: II, 63). Also by virtue of this unique atmosphere, these processions set up a temporal, and temporary, framework conducive to a collective suspension, meditation, and (self-)reflection, dramatically displayed and embodied by the slow or very slow, cadenced, more or less swinging movements ${ }^{20}$ (so distant from those we are used to experience in daily life) performed by the brothers who switch between walking and stopping (Bronzini 1974: II, 62). What is more, they transmit these movements to the simulacra carried on their shoulders or in their arms; in so doing, they infuse a sort of life into those inanimate figures: a transitory yet vividly symbolic, theatrical, touching life. ${ }^{21}$ As pointed out by Buttitta (2002: 206-207):

From a religious and spiritual point of view, they [processions] must prove that "the sacred is not geographically confined in a given place, but is able to occupy, for the time being, other places.”... They are a means through which humans mythically display their own world, then the conception of time and space on which it is based [in a word, a chronotope].

This mythical re-configuration of time and space, chiefly performed through the processions - symbolic fictions, indeed - and basically founded on the permutation and blending of sacred and secular elements of the urban landscape, may not be understood, at any rate, outside its religious, devotional paradigm. The analysis of fieldwork and archival materials shows that the structure and meanings of the processional rituality of the Holy Week fundamentally lie in a ritual tripartition depending on the Christian calendar. In fact, the Last Supper, the Passion (including the Death as one of its Mysteries) and the Death of Christ (associated to or replaced by the Sorrows of the Virgin Mary), ${ }^{22}$ more or less linked, respectively, with Maundy Thursday, Good Friday, and Holy Saturday, constitute the mythical stages of a sacred space-time frame within which the Apulian communities organize their ritual cosmos. However, this mythical, sacred triduum is arranged in different ways - as exemplified above - with regard to the overall structure as well as the features of the related dramatic performances. This is a significant variety, since it is illuminating both as to the different ways of conceiving and living a shared cultural heritage within a more or less homogeneous geographical area, and as to the dialectic between 
religious, liturgical and/or ritual rules and their contextual, vernacular, historical adaptations and modifications. As told by my informant Leonardo, in response to a question about the decoration of a church's altar for Maundy Thursday: "If you follow the liturgical rules, you are free to do what you want. Year after year the altar's decoration is always different, every year it is reinvented" (Carrassi 2016: 116).

\section{CONCLUSION}

Generally speaking, within and through the liminal chronotope emerging from the Holy Week's ritual performances, most Apulian communities still express and (re)shape a significant part of themselves and, at the same time, try to find their own way to make their local identity globally more recognizable and valuable (cf. Bendix 2018). And the processions, in this time of heritagization (see, in particular, Inglis \& Holmes 2003; Poria 2010) and cultural tourism, are certainly effective, striking means that cities and towns have to make known and promote, first of all, their religious and traditional beliefs and practices, which are part and parcel of their immaterial or intangible heritage. Nevertheless, just due to the itinerant mode of processions, cities and towns can make known and promote also their most valuable buildings, their main squares and streets, that is to say, their material or tangible heritage. In other words, the Holy Week's ritual performances, by their own nature and their more or less dynamic and spectacular forms, allow a quite complete display and enhancement of a cultural, local, peculiar heritage; they turn a place into a meaningful location and define its uniqueness as a destination for inhabitants and visitors alike (Hafstein 2018: 137; Kirshenblatt-Gimblett 1998). In this light, everywhere during my fieldwork a prominent need was noticeable to preserve the processions, then to preserve what is generally felt and regarded as their traditional identity, their authenticity, despite the several and increasingly fast innovations affecting the world around them (Carrassi 2018: 171-174). For many people, indeed, especially for the emigrants coming back to their native cities or towns for the Easter holidays, these processions become effective means to recover a (lost) sense of belonging. Accordingly, the bearers of the related traditions, chiefly the active, but partly also the passive ones (Sydow 1948: 12-15), are called to make a collective effort to contain changes and transformations as much as possible. Nicola, one of my informants, expressly talks about a danger of "folklorization" (cf. Hafstein 2018: 131-134) looming over the Holy Week's ritual performances; he wishes, and actually struggles (both as a brother and a local historian), for 
the preservation and revitalization of their most "authentic" meaning, which is, in his view, the religious and spiritual one (personal communication 2015). Only in this way, after all, the processions are thought to keep their purpose as recognizable and convincing features of a (presumed) traditional, authentic identity, namely of a uniqueness worth to be heritagized, or even to be included in a UNESCO's list, nowadays almost an obsession for individuals, groups, and communities engaged in the identification and safeguarding of a cultural heritage (Jansen-Verbeke 2016; Hafstein 2018: 139-144). Heritagization, mediatization, objectification, and commercialization are all ongoing phenomena connected with a "reflexive modernization" (Beck \& Giddens \& Lash 1994) which, by its safeguarding policies and strategies, "reforms the relationship of subjects with their own practices ... reforms the practices ... and ultimately reforms the relationship of the practicing subjects with themselves" (Hafstein 2018: 128). Notwithstanding, while these phenomena have certainly affected and increasingly affect the contexts and the actors - some informants, for instance, stressed a growing interest and participation, especially of young people, in the confraternities and the Holy Week's rituals - the functions and the meanings, fluctuating between a re-enchanted sense of the world and a need to take a break from the daily and working routine, and the organization and the perception of the ritual practices here addressed, my fieldwork and my direct experience as an Apulian inhabitant evidence a substantial continuity of forms, patterns and rules characterizing the processions. In effect, despite the changing landscapes and the changing mankind attending them, the Holy Week's processions basically remain traditional performances that, for a few or a number of hours, for one or more days, stage a liminal experience by occupying the ordinary spaces of everyday life. In so doing, they temporarily suspend the ordinary flow of time to make room for another kind of time: today as yesterday, mutatis mutandis, a reflexive and self-reflexive kind of time.

\section{NOTES}

1 The fieldwork consisted of participant observation, visual documentation, and interviews with informants and participants of the rituals and festivals addressed. Further materials presented in this article have been collected through an independent research carried out in 2017.

2 The processions are conceivable as "multimedial performances", since they "create situations in which language, movements, spaces, and objects can all be coordinated in powerfully symbolic ways" (Frog 2017: 583). 
${ }^{3}$ Cf. the concept of "performance arena" (Foley 1995: 47-49), about which Frog (2017: $600)$ writes: "Rather than a physical location, the performance arena is an experience-based framework that is internalized through exposure to, and participation in, a performance tradition. When the tradition is encountered, the performance arena is reciprocally activated as a framework for the reception and interpretation of relevant expressions."

4 Drawing on a classic work of Michel de Certeau (1984: 29-41, 91-111), the streets can function both as "strategic" tools to organize the city/town from the above (at an institutional and official level), and as "tactical" resources to explore and (re)invent the urban spaces from the below (at an individual and unofficial level).

5 Clearly, the Bakhtinian (high) road, which allows the inter-connection between towns or cities, is not the same as a street, which instead connects the places making up the urban setting. Nonetheless, both of them are, after all, ways of communications and relationships, so I think that the chronotope of the "road" may be profitably permuted as a tool to analyze the "street".

6 “... the chronotope of threshold ... can be combined with the motif of encounter, but its most fundamental instance is as the chronotope of crisis and break in a life. The word 'threshold' itself already has a metaphorical meaning in everyday usage (together with its literal meaning), and is connected with the breaking point of a life, the moment of crisis, the decision that changes a life (or the indecisiveness that fails to change a life, the fear to step over the threshold).... In this chronotope, time is essentially instantaneous; it is as if it has no duration and falls out of the normal course of biographical time" (Bakhtin 2002: 21, emphasis mine).

7 Like in the second stage ("transition" or "liminal phase") of the tripartite frame theorized by Arnold Van Gennep (2004 [1960]: 10-12) for the rites of passage.

8 For an up-to-date and quite complete overview of the main processions organized and performed in Apulia during the Holy Week I refer to an online resource: https://www. settimanasantainpuglia.it/content/index.asp, last accessed on 12 March 2020.

9 Interestingly, my informant Enzo reported that the procession of Mysteries in Taranto, established in 1765 and performed for almost two centuries across the alleys of the old part of the city (Taranto Vecchia), approximately from 1964, following an extemporaneous initiative of a brother, started to be performed in the modern part of the city (Borgo), thus leaving the previous route (personal communication 2014).

${ }^{10}$ In my hometown, Castellaneta (as well as in Taranto), there are eight simulacra, which represent the following Mysteries: Christ in the Gethsemane, Christ mocked with a cane in hand, Christ tortured at a column, Christ carrying the Cross, Christ crucified, the Piety, the Dead Christ, and Our Lady of Sorrows.

11 The processions of the Holy Saturday, albeit with some minor variations (they generally consist of a smaller number of simulacra and performers), fundamentally conform to the pattern described for Good Friday (cf. Bernardi 1991: 124-129).

12 The confraternity of Saint Peter has only the simulacrum of Our Lady of Sorrows, while that of the Mount Carmel has four extra simulacra representing as many Mysteries. 
${ }^{13}$ As a rule, among the participants in the processions, there are men appointed to collect offerings from the audience and deliver printed pictures representing subjects related to the procession.

${ }^{14}$ Cf. Hafstein 2018 (134): “... objectification of the practices and expressions makes them transferable and is the first step toward their alienation from the source community.... The paradox here is that the principal incentive for inscription on national or international heritage lists is precisely to promote these festivals ... to attract more tourists, and to increase rather than limit their circulation; many of the tools used to safeguard intangible heritage are geared to these ends, including, notably, the festival."

${ }^{15}$ For a historical overview of this subject, limited to the Apulian context, I refer to Bertoldi Lenoci 1988-1990, and Gelao 1994.

16 This kind of brotherhood may be regarded as a form of communitas, which Turner (1969: 96) describes as "an unstructured or rudimentarily structured and relatively undifferentiated comitatus, community, or even communion of equal individuals who submit together to the general authority of the ritual elders".

${ }^{17}$ In a little town such as Vico del Gargano (about 8,000 inhabitants), for instance, there are five confraternities: Holy Sacrament, Death and Oration, Saint Augustine and Saint Monica, Mount Carmel, and Saint Peter. There are also five confraternities in Castellaneta (about 17,000 inhabitants): Holy Sacrament, Our Lady of Sorrows, Our Lady of the Rosary, Saint Francis of Paola, and the recently re-established Crucifix.

${ }^{18}$ For instance in Francavilla Fontana, Noicattaro, Molfetta, and Gallipoli.

${ }^{19}$ Buttitta (2002: 210) explains that the role played by the confraternities is "expressed by a complex language consisting of behaviors, images and ritual objects".

20 The swinging movement, one of the most distinctive features of the brothers in procession, is vernacularly known in Taranto as nazzecata or nazzicata, and is explained by my informant Enzo with the fact that the procession, as such, must always "proceed" and never stop; therefore, by swinging, the brothers keep moving even when they have to stop their walking, especially before and within the churches met along the route (verbal communication 2014).

${ }^{21}$ Cf. Buttitta 2012: 698-699: "During the festival days, instead [i.e. differently from when it is within the church], the simulacrum transfigures, becomes animate; it is the Saint. It is the host turning into flesh, the wine turning into blood. The sacred, then, becomes describable, revealing itself entirely into space and time: it is the hierophany in its deepest sense."

${ }^{22}$ Curiously, the Resurrection - which should be the most important and celebrated of the Christian dogmas - except a few towns (such as Francavilla Fontana, Ruvo di Puglia, Troia, and San Marco in Lamis), is by and large neglected as a subject of specific processions. Apparently, it is seen and felt as an event, a Mystery too sacred and beyond the human understanding (and maybe not sufficiently touching and theatrical) to be suitable for a purely material dramatic performance. 


\section{SOURCES}

Fieldwork materials from 2013-2017 in possession of the author.

\section{REFERENCES}

Altomare, Tito Manlio 2011. Puglia in festa. [Festive Apulia.] Bari: Adda.

Bakhtin, Mikhail M. 1984. Rabelais and His World. Bloomington: Indiana University Press.

Bakhtin, Mikhail M. 2002. Forms of Time and of the Chronotope in the Novel: Notes toward a Historical Poetics. In: Brian Richardson (ed.) Narrative Dynamics: Essays on Time, Plot, Closure, and Frames. Columbus: The Ohio State University Press, pp. 15-24.

Beck, Ulrich \& Giddens, Anthony \& Lash, Scott 1994. Reflexive Modernization: Politics, Tradition, and Aesthetics in the Modern Social Order. Cambridge: Polity Press.

Bendix, Regina F. 2018. Culture and Value: Tourism, Heritage, and Property. Bloomington: Indiana University Press.

Bernardi, Claudio 1991. La drammaturgia della Settimana Santa in Italia. [The Dramaturgy of the Holy Week.] Milano: Vita e Pensiero.

Bertoldi Lenoci, Liana (ed.) 1988-1990. Le confraternite pugliesi in età moderna. [Apulian Confraternities in the Modern Age.] Fasano: Schena, 2 vols.

Blommaert, Jan 2018. Are Chronotopes Helpful? Working Papers in Urban Language and Literacies. Paper 243. London: King's College. Available at https://www. academia.edu/36905272/WP243, last accessed on 12 March 2020.

Bravo, Gian Luigi \& Tucci, Roberta 2006. I beni culturali demoetnoantropologici. [The Demo-Ethno-Anthropological Cultural Heritage.] Roma: Carocci.

Bronzini, Giovanni Battista 1974. Lineamenti di storia e analisi della cultura tradizionale. [An Outline of History and Analysis of Traditional Culture.] 2 vols. Roma: Edizioni dell'Ateneo.

Buttitta, Ignazio E. 2002. Rifondare lo spazio: La Settimana Santa a Caulonia. [Refounding the Space: The Holy Week in Caulonia.] In: Ignazio E. Buttitta: La memoria lunga: Simboli e riti della religiosità tradizionale. Roma: Meltemi, pp. 189-221. Available at https://www.academia.edu/1224460/, last accessed on 12 March 2020.

Buttitta, Ignazio E. 2012. Simulacri divini: Ruoli cultuali e pratiche devozionali. [Divine Simulacra: Cult Roles and Devotional Practices.] In: Teresa Pugliatti \& Salvatore Rizzo \& Paolo Russo (eds.) Manufacere et scolpire in lignamine: Scultura e intaglio in Sicilia tra Rinascimento e Barocco. Catania: Giuseppe Maimone Editore, pp. 691-704.

Caputo, Nicola 1995 [1989]. I giorni del perdono: guida ai riti della Settimana Santa a Taranto. [Forgiveness Days: A Guidebook to the Holy Week's Rituals in Taranto.] Taranto: Scorpione. 
Caputo, Nicola 2010 [1983]. L'anima incappucciata: La Settimana Santa a Taranto e le processioni dell'Addolorata e dei Misteri dalle origini ad oggi a Taranto. [The Hooded Soul: The Holy Week in Taranto and the Processions of Our Lady of Sorrows and of Mysteries from the Origins to the Present.] Taranto: Mandese.

Carrassi, Vito 2016. Il dramma rituale del Venerdì Santo a Vico del Gargano. [The Ritual Drama of the Good Friday.] In: N. Blasi \& V. Carrassi \& V. Di Natale (eds.) La memoria che vive 2: Musica e arti nella tradizione popolare, fra ricerca, catalogazione e diffusione. Bari: WIP Edizioni, pp. 111-122.

Carrassi, Vito 2018. Deconstructing and Reconstructing Irish Folklore: The Irreverent Parody of An Béal Bocht. In: A. Maillot \& J. Bruen \& J.-P. Imbert (eds.) NonViolent Resistance: Irreverence in Irish Culture. Oxford: Peter Lang, pp. 171-186.

Certeau, Michel de 1984. The Practice of Everyday Life. Berkeley: University of California Press.

Di Palo, Francesco 1992. Stabat Mater dolorosa. La Settimana Santa in Puglia: ritualità drammatica e penitenziale. [Stabat Mater Dolorosa. The Holy Week in Apulia: Dramatic and Penitential Rituality.] Fasano: Schena.

Foley, John Miles 1995. The Singer of Tales in Performance. Bloomington: Indiana University Press.

Frog 2017. Multimedial Parallelism in Ritual Performance (Parallelism Dynamics II). Oral Tradition, Vol. 31, No. 2, pp. 583-620. http://dx.doi.org/10.1353/ort.2017.0022.

Gelao, Clara (ed.) 1994. Confraternite, arte e devozione in Puglia dal Quattrocento al Settecento. [Confraternities, Art and Devotion in Apulia from the Fifteenth to the Eighteenth Century.] Napoli: Electa.

Hafstein, Valdimar Tr. 2018. Intangible Heritage as a Festival; or, Folklorization Revisited. Journal of American Folklore, Vol. 131, No. 520, pp. 127-149. DOI: 10.5406/jamerfolk.131.520.0127.

Inglis, David \& Holmes, Mary 2003. Highland and Other Haunts: Ghosts in Scottish Tourism. Annals of Tourism Research, Vol. 30, No. 1, pp. 50-63. https://doi. org/10.1016/S0160-7383(02)00031-2.

Jansen-Verbeke, Myriam 2016. Foreword. In: M.D. Alvarez \& F.M. Go \& A. Yüksel (eds.) Heritage Tourism Destinations: Preservation, Communication and Development. Boston: CAB International, pp. xii-xiv.

Kirshenblatt-Gimblett, Barbara 1998. Destination Culture: Tourism, Museums, and Heritage. Berkeley \& Los Angeles \& London: University of California Press.

Krom, Maria J.C. 2009. Contested Spaces. Meaningful Places. Contemporary Performances of Place and Belonging in Spain and Brazil. Journal of Ethnology and Folkloristics, Vol. 3, No. 2, pp. 33-46. Available at http://jef.ee/index.php/journal/ issue/view/2, last accessed on 12 March 2020.

Leach, Edmund 1976. Culture and Communication: The Logic by Which Symbols Are Connected. Cambridge: Cambridge University Press. https://doi.org/10.1017/ CBO9780511607684.001.

Lenzini, Francesco 2017. Riti urbani: Spazi di rappresentazione sociale. [Urban Rituals: Spaces of Social Performance.] Macerata: Quodlibet.

McKercher, Bob \& du Cros, Hilary 2012 [2002]. Cultural Tourism: The Partnership between Tourism and Cultural Heritage Management. London \& New York: Routledge. 
Nigro, Raffaele 2002. Puglia: Viaggio nelle tradizioni e nel folklore. [Apulia: A Travel across the Traditions and the Folklore.] Bari: Adda.

Pizzuti, Domenico \& Di Gennaro, Giacomo \& Martelli, Stefano \& Sarnataro, Ciro (eds.) 1998. La religiosità nel Mezzogiorno: persistenza e differenziazione della religione in un'area di trasformazione. [The Religiousness in Southern Italy: Persistence and Differentiation of Religion in a Transforming Area.] Milano: FrancoAngeli.

Poria, Yaniv 2010. The Story behind the Picture: Preferences for the Visual Display at Heritage Sites. In: E. Waterton \& S. Watson (eds.) Culture, Heritage and Representation: Perspectives on Visuality and the Past. Farnham \& Burlington: Ashgate, pp. 217-228.

Ringer, Greg (ed.) 1998. Destinations: Cultural Landscapes of Tourism. London \& New York: Routledge.

Rivera, Annamaria 1988. Il mago, il santo, la morte, la festa: Forme religiose nella cultura popolare. [The Sorcerer, the Saint, the Death, the Festival: Religious Forms in the Popular Culture.] Bari: Dedalo.

Sydow, Carl Wilhelm von 1948. On the Spread of Tradition. In: L. Bødker (ed.) Selected Papers on Folklore. Copenhagen: Rosenkilde and Bagger, pp. 11-43.

Toschi, Paolo 1955. Le origini del teatro italiano. [The Origins of the Italian Theatre.] Torino: Einaudi.

Turner, Victor 1967. Betwixt and Between: The Liminal Period in Rites de Passage. In: The Forest of Symbols: Aspects of Ndembu Ritual. Ithaca, NY \& London: Cornell University Press, pp. 93-111.

Turner, Victor 1969. The Ritual Process: Structure and Anti-Structure. Chicago: Aldine Publishing.

Turner, Victor 1982. From Ritual to Theatre: The Human Seriousness of Play. New York: PAJ Publications. Available at https://monoskop.org/images/7/79/Turner_Victor_ From_Ritual_to_Theatre.pdf, last accessed on 12 March 2020.

Turner, Victor 1988. The Anthropology of Performance. New York: PAJ Publications. Van Gennep, Arnold 2004 [1960]. The Rites of Passage. London: Routledge.

Vito Carrassi is an independent scholar $(\mathrm{PhD})$, former teacher of folkloristics. His main research areas are folk beliefs and narratives, orality/literacy studies, ritual year and folklore/folklorism.

vito1976@interfree.it 